\title{
OPETTAJAOPISKELIJOIDEN ÄÄNIOIREET JA NIIDEN YHTEYS KOETTUUN PSYKOSOSIAALISEEN HAITTAAN SEKÄ ARVIOON OMASTA ÄÄNENLAADUSTA - ERI OPETTAJANKOULUTUSALOJEN VERTAILU
}

\author{
Roosa Britschgi, Coronaria kuntoutus Oy \\ Jaana Sellman, Motivoice Oy
}

Tämä tutkimus tarkastelee eri opettajankoulutusalojen opiskelijoiden äänioireita, heidän äänensä vuoksi kokemaa psykososiaalista haittaa sekä kokemusta oman äänensä häiriöisyydestä. Eri oppiaineiden opettamiseen liittyy erilaisia kuormittavia tekijöitä ja joidenkin alojen opettajilla on havaittu muita enemmän äänioireita. Opettajaopiskelijoiden on todettu kokevan jo opiskeluvaiheessa muita yliopisto-opiskelijoita enemmän äänioireita, mutta sitä, esiintyykö jonkin oppiaineen opettajaopiskelijoilla enemmän äänioireita jo opiskeluvaiheessa, ei ole aiemmin vertailtu. Aiemmassa tutkimuksessa äänioireiden ja psykososiaalisen haitan väliltä on löydetty tilastollinen yhteys, mutta suomalaistutkimuksissa tätä yhteyttä ei ole aiemmin tarkasteltu.

Tähän kyselytutkimukseen osallistui 190 Helsingin yliopiston opettajankoulutuslaitoksen kuuden eri koulutusalan opiskelijaa kaikilta vuosikursseilta. Aineisto kerättiin sähköisellä kyselylomakkeella, joka sisälsi äänioirekyselyn, psykososiaalista haittaa kartoittavan VHI-kyselyn sekä taustatietokyselyn.

Tutkimus osoitti, että lähes $40 \%$ : ia opettajankoulutuslaitoksen opiskelijoista kokee säännöllisiä äänioireita. Tutkimuksessa havaittiin kuitenkin, että säännöllisistä äänioireistaan huolimatta useimmat (80\%) opiskelijat pitävät ääntään normaalina eikä suurin osa (90\%) kokenut äänensä vuoksi mainittavaa psykososiaalista haittaa. Eri koulutusalojen välillä ei ollut havaittavissa eroja äänioireiden tai psykososiaalisen haitan määrässä.

Avainsanat: kyselytutkimus, oman äänen arvio, opettajaopiskelijat, psykososiaalinen haitta, äänioire

\section{JOHDANTO}

Opettajien ja lastentarhanopettajien työhön kuuluva jatkuva äänenkäyttö, toisinaan kovassakin taustamelussa, kuormittaa ääntöelimistöä (mm. Titze, 2001) ja asettaa suuret

\footnotetext{
Kirjoittajien yhteystiedot:

Roosa Britschgi, Coronaria kuntoutus Oy

roosa.britschgi@coronaria.fi

Jaana Sellman, Motivoice Oy

jaana.sellman@helsinki.fi
}

vaatimukset äänen kestävyydelle. Äänioireet ovatkin yleisiä eri alojen opettajilla (Sala, Airo, Olkinuora, Simberg, Ström, Laine, Pentti \& Suonpää, 2002). Äänikuormituksen riskitekijät voivat vaihdella opettajan erikoistumisalasta riippuen. Lastentarhanopettajilla (mm. Sala ym., 2002, Kankare, Geneid, Laukkanen \& Vilkman, 2012), liikunnanopettajilla (Cantor Cutiva, Vogel \& Burdorf, 2013) ja taide-aineiden opettajilla (Thibeault, Merril, Nelson, Gray \& Smith, 2004) on todettu 
esiintyvän enemmän äänioireita suhteessa muihin opettajiin. Oireita esiintyy jo usein opiskeluaikana, ennen varsinaista työelämää. Jopa kolmanneksella opettajaopiskelijoista äänioireita on todettu esiintyvän säännöllisesti (mm. Fairfield \& Richards, 2007; Thomas, Kooijman, Cremers \& de Jong, 2006) ja viidesosalla on todettu orgaanisia eli elimellisiä muutoksia ääntöelimistössä (Simberg, 2004, s. 25). Opettajaopiskelijoilla on todettu esiintyvän enemmän äänioireita kuin muilla opiskelijoilla (Simberg, Sala \& Rönnemaa, 2004), ja opiskeluaikaisten äänioireiden on todettu viittaavaan suurempaan riskiin kokea äänioireita myös myöhemmin työelämässä (Thomas ym., 2006). Sitä, onko eri opettajankoulutusalojen opiskelijoiden äänioireiden esiintyvyydessä eroja, ei ole aiemmin vertailtu.

Äänioireet heikentävät puhetyöläisten työkykyä ja rajoittavat vapaa-ajan toimintaa, mikä heijastuu usein negatiivisesti myös mielialaan ja elämänlaatuun (Sala, Sihvo \& Laine, 2003, s. 28-29). Äänioireet voivat vaikuttaa esimerkiksi ammatillisen itsetunnon kehitykseen ja aiheuttaa epävarmuutta ja jännitystä omasta suoriutumisesta tulevassa opettajan työssä (Ilomäki, 2008, s. 20). Äänioireiden aiheuttama haittakokemus on kuitenkin yksilöllinen, joten äänioireiden määrästä ei voida suoraan päätellä sitä, kuinka paljon haittaa oireista yksilölle aiheutuu (Stemple, Glaze \& Gerdeman Klaben, 2010, s. 128, 169). Tässä tutkimuksessa kartoitettiin eri opettajankoulutusalojen opiskelijoiden äänioireita ja niiden vaikutusta heidän elämänlaatuunsa. Tutkimuksen tavoitteena oli selvittää, kuinka paljon eri alojen opettajaopiskelijoilla esiintyy äänioireita, ja kuinka suurta haittaa he kokevat äänioireistaan olevan. Lisäksi selvitettiin, miten koetut äänioireet, subjektiivisesti arvioitu psykososiaalinen haitta ja itsearvioitu äänen häiriöisyysaste ovat yhteydessä toisiinsa. Näiden ohella tarkasteltiin myös, mitkä taustatekijät ovat yhteydessä opiskelijoiden kokemiin äänioireisiin, haittaan ja äänen häiriöisyyteen.

\section{MENETELMÄT}

\section{Tutkittavat}

Helsingin yliopiston opettajankoulutuslaitoksessa opiskelee vuosittain lähes 3000 puheammattiin valmistuvaa opiskelijaa. Suurin osa heistä opiskelee luokanopettajaksi. Muita koulutusaloja ovat aineenopettajan koulutus, varhaiskasvatuksen koulutus, kotitalousopettajan koulutus, käsityönopettajan koulutus sekä erityispedagogiikan koulutus.

Tutkimuksen aineisto kerättiin sähköisen strukturoidun kyselylomakkeen avulla. Kysely lähetettiin kaikille Helsingin yliopiston opettajankoulutuslaitoksen ainejärjestöjen sähköpostilistoilla oleville opiskelijoille ( $\mathrm{n}=2220)$ maaliskuussa 2015. Tutkimukseen vastasi 190 opiskelijaa eli vastausprosentti oli 8,6 \%. Vastaajia oli kaikilta vuosikursseilta ja kaikista kuudesta koulutusosastosta. Eniten vastauksia saatiin aineenopettajaopiskelijoilta $(\mathrm{n}=54)$. Suhteessa koulutuslinjan kokoon aktiivisimpia vastaajia olivat käsityötieteen koulutuksen opiskelijat, joista $25 \%$ vastasi tutkimukseen (ks. taulukko 1). 
Taulukko 1. Tutkittavat koulutusaineittain.

\begin{tabular}{|l|c|c|c|}
\hline Koulutusaine & $\begin{array}{c}\text { Kyselyyn } \\
\text { vastanneet } \\
(\mathbf{n})\end{array}$ & $\begin{array}{c}\text { Vastanneiden osuus } \\
\text { kaikista tutkittavista } \\
(\mathbf{\%})\end{array}$ & $\begin{array}{c}\text { Vastanneiden osuus } \\
\text { ko. koulutusaineen } \\
\text { opiskelijoista (\%) }\end{array}$ \\
\hline Aineenopettaja & 54 & 28,4 & 8,6 \\
\hline Luokanopettaja & 39 & 20,5 & 4,3 \\
\hline Käsityötiede & 30 & 15,8 & 25,0 \\
\hline Kotitaloustiede & 29 & 15,3 & 14,5 \\
\hline Varhaiskasvatus & 27 & 14,2 & 7,9 \\
\hline Erityispedagogiikka & 11 & 5,8 & 12,2 \\
\hline YHTEENS $\ddot{A}$ & $\mathbf{1 9 0}$ & $\mathbf{1 0 0}$ & - \\
\hline
\end{tabular}

\section{Arviointimenetelmät}

Opiskelijoiden äänen tilannetta kartoitettiin sähköisellä strukturoidulla kyselylomakkeella, joka koostui kolmesta osiosta. Äänioireiden esiintyvyyttä selvitettiin äänioirekyselyl$l \ddot{a}$ (voice screening test; ks. liite) (Simberg, Sala, Laine \& Rönnemaa, 2001) ja äänioireiden aiheuttamaa psykososiaalista haittaa Voice Handicap Index -kyselyllä eli VHI:llä (Jacobson ym., 1997; suomenkielinen versio Alaluusua \& Johansson, 2003). Lisäksi selvitettiin taustatekijöiden, kuten aiempien äänihäiriöiden, ylähengitysteiden infektioiden ja refluksin esiintymistä sekääänikuormitukseen liittyviä ominaisuuksia, kuten arviota äänen korkeudesta ja äänen käytön määrästä vapaaajalla. Koulutusten välistä vertailua varten vastaajilta kysyttiin taustatiedoissa muun muassa koulutusalaa, vuosikurssia ja sukupuolta. Kysely koostui enimmäkseen suljetuista kysymyksistä ja monivalinnoista. Laadullisen lisätiedon saamiseksi kysely sisälsi kuitenkin myös avoimen kommentointikentän.

\section{Aineiston analyysi}

Aineiston tilastollisessa analysoinnissa käytettiin IBM SPSS 22-tilasto-ohjelmaa. Tutkimusotoksen perustietoja varten vastauksista laskettiin frekvenssejä eli havaintojen esiintymismääriä sekä niiden prosenttiosuuksia. Koska normaalijakauma oletus ei toteutunut ja suurin osa mittauksista oli lisäksi suoritettu järjestysasteikolla, tilastollisessa tarkastelussa käytettiin epäparametrisia testejä (Nummenmaa, 2008, s. 143).

Äänioireiden esiintymisen perusteella tutkittavien joukko $(\mathrm{n}=190)$ jaettiin kahteen ryhmään. Äänioirekyselyssä jatkotutkimuksiin hakeutumisen rajana on pidetty kahta vähintään viikoittaista oiretta (Simberg, 2004), joten äänioireisten ryhmän $(\mathrm{n}=70)$ muodostivat opiskelijat, joilla oli vähintään kaksi viikoittain tai useammin esiintyvää oiretta. Loput opiskelijat $(\mathrm{n}=120)$ muodostivat äänioireettomien ryhmän. Äänioireisten ja äänioireettomien ryhmien tilastolliseen vertailuun käytettiin Mann-Whitneyn U-tes- 
tiä. Kun vertailtavia ryhmiä oli useita, kuten eri koulutusten eroja tarkastellessa, käytettiin Kruskal-Wallis -testiä. Mann-Whitneyn U-testiä ja Kruskall-Wallisia yhteydessä käytettiin p-arvojen korjausmenetelmäna Bonferroni-korjausta, joka huomio usean t-testin yhtäaikaisen käytön aiheuttaman riskin löytää sattumalta merkitsevä yhteys. Korrelaatioita, eli kahden muuttujan välisiä riippuvuussuhteita tarkasteltiin Spearmanin järjestyskorrelaatiokertoimen (Spearman's rho $=r_{s}$ ) avulla. Avoimet kommentit luokiteltiin teemoittain, ja löydettyjä teemoja tarkasteltiin kvantifioiden eli laskemalla niiden esiintymiskertoja kommenteissa. Samassa kommentissa saatettiin mainita useita teemoja. Kvantifioinnin avulla nähtiin, mitä asioita opiskelijat itse eniten nostivat esiin. Avoimissa kommenteissa esiin nousseita teemoja pohdittiin myös laadullisesti suhteessa tutkimuksessa esiin nousseisiin ilmiöihin.

\section{TULOKSET}

\section{Ä̈nioireiden esiintyvyys}

Säännöllisiä äänioireita, toisin sanoen vähintään kahta viikoittain tai useammin esiintyvää äänioiretta, koki useampi kuin joka kolmas (37\%) opettajaopiskelija. Täysin oireettomia oli vain neljä (2\%) vastaajaa. Äänioirekyselyn keskiarvo oli 7 pistettä ja yhteispisteet vaihtelivat minimipisteistä (0) maksimipisteisiin (21). Yleisimmin koettuja äänioireita olivat äänen käheys aamuisin, äänen väsyminen sekä tarve selvittää kurkkua puhumisen aikana (ks. kuva 1). Vähiten esiintyi äänen sortumista tai pettämistä sekä vaikeutta saada ääntä kuulumaan. Opettajankoulutuslaitoksen eri koulutusalojen opiskelijoiden välillä ei havaittu tilastollisesti merkitseviä eroja äänioireiden määrässä.

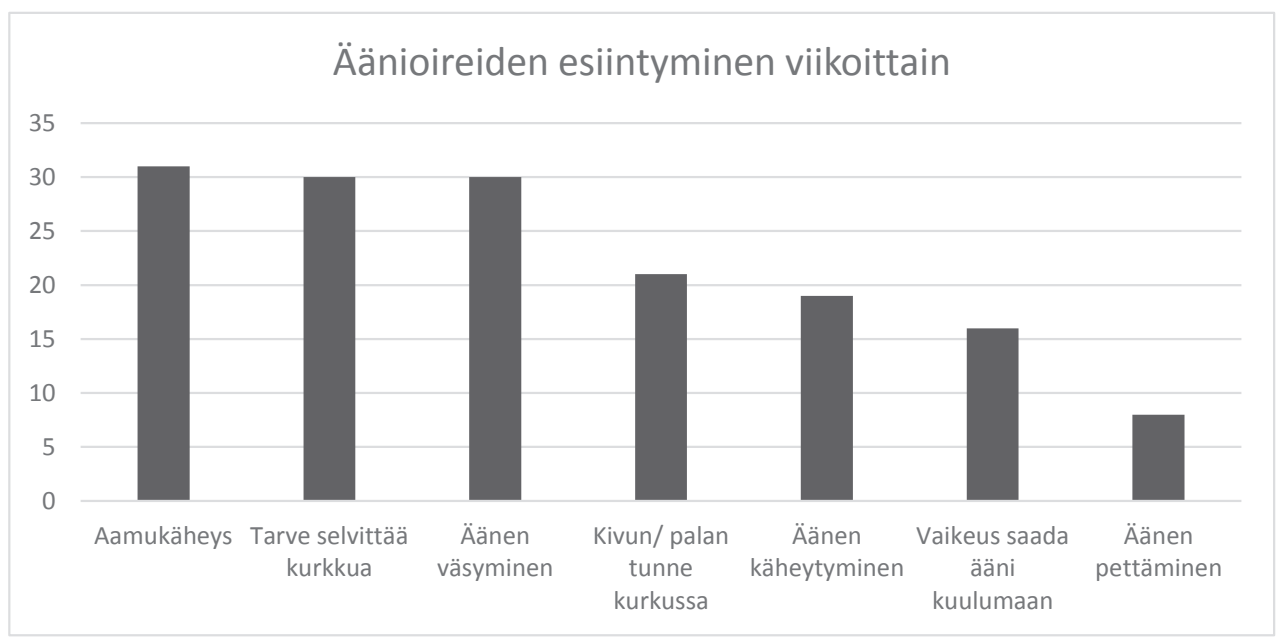

Kuva 1. Vähintään viikoittaisten äänioireiden prosentuaalinen esiintymistiheys kaikilla tutkituilla. 
Taustatekijöitä tarkasteltaessa voitiin havaita, että opiskelijat kokivat äänioireita etenkin harjoitteluiden ja sijaisuuksien yhteydessä. Joka neljäs opiskelija oli kokenut äänioireita harjoitteluiden aikana ja useampi kuin joka kolmas sijaisuuksia tehdessään. Suurin osa (61\%) opiskelijoista myös jännitti äänensä kestämistä tulevassa työssään. Äänioirekyselyn perusteella äänioireisten ryhmään luokitellut opiskelijat kokivat enemmän ääniongelmia sekä harjoitteluissa että töissä ja jännittivät äänensä kestämistä selvästi enemmän kuin äänioireettomien ryhmään kuuluneet opiskelijat. Äänioireisten ryhmään kuuluvat opiskelijat olivat opinnoissaan pidemmällä kuin äänioireettomien ryhmään kuuluvat opiskelijat $(p<.01)$. He olivat keksimäärin viidennen vuoden opiskelijoita (ka. 4,3, Md 5), kun taas äänioireettomien ryhmään kuuluvien opiskelijat olivat keskimäärin kolmannen vuosikurssin opiskelijoita (ka.3,2, Md 3). Äänioireisten ryhmään kuuluvilla opiskelijoilla esiintyi tilastollisesti merkitsevästi enemmän $(p<.01)$ viikoittaista närästystä, ylätieinfektioita. Lisäksi kaikki opiskelijat, joilla oli aiemmin diagnosoitu äänihäiriö, kuuluivat äänioireisten ryhmään.

Koetuista äänioireista huolimatta $77 \%$ opiskelijoista arvioi oman äänensä normaaliksi (ks. taulukko 2). Lievästi häiriöisenä ääntään piti 40 vastaajaa $(21 \%)$ ja melko häiriöisenä neljä vastaaja (2\%). Yksikään opiskelija ei arvioinut ääntään äärimmäisen häiriöiseksi.

Taulukko 2. Opettajaopiskelijoiden ( $n=190)$ arviot oman äänensä häiriöisyydestä ja äänioireiden vuoksi koetusta psykososiaalisesta haitasta.

\begin{tabular}{|c|c|}
\hline & $\begin{array}{l}\text { Opettaja-opiskelijat } \\
\text { n (\%) }\end{array}$ \\
\hline $\begin{array}{l}\text { Äänen häiriöisyys } \\
\text { • normaali } \\
\text { • lievästi häiriöinen } \\
\text { • melko häiriöinen } \\
\text { • äärimmäisen häiriöinen }\end{array}$ & $\begin{array}{l}146(77) \\
40(21) \\
4(2) \\
0(0)\end{array}$ \\
\hline $\begin{array}{l}\text { Psykososiaalinen haittakokemus } \\
\text { - ei mainittavaa haittaa } \\
\text { - lievä haitta } \\
\text { - kohtalainen haitta } \\
\text { - huomattavan suuri haitta }\end{array}$ & $\begin{array}{l}169(89) \\
11(6) \\
8(4) \\
2(1)\end{array}$ \\
\hline
\end{tabular}

Tässä tutkimuksessa VHI-kyselyn yhteispisteet vaihtelivat välillä $0-62$ ja kokonaispistemäärän keskiarvo oli 15 pistettä. VHIkyselyn korkein mahdollinen yhteispistemäärä on 120 pistettä. Opettajankoulutuslaitoksen eri koulutusalojen välillä ei ollut tilastollisesti merkitseviä eroja VHI:n kokonaispistemäärissä. Noin $90 \%$ opettajaopiskelijoista ei kokenut äänioireidensa vuoksi mainittavaa psykososiaalista haittaa, toisin sanoen heidän VHI-kyselynsä kokonaispistemäärä jäi alle 33 pisteen (ks. taulukko 2). Lievää haittaa (33-43p.) koki 11 vastaajaa (6\%), kohtalaista haittaa (44-60p.) kahdeksan vastaajaa (4\%) ja huomattavan suurta haittaa (yli 61p.) kaksi vastaajaa (1\%). Tässä tutkimuksessa käytetyt pisterajat perustuvat Jacobson ym. (1997) määritelmiin. VHI-suomennoksesta 
tehdyssä tutkimuksessa (Alaluusua \& Johansson, 2003) pisterajat on määritelty kyseisen tutkimuksen VHI-pisteiden keskiarvojen perusteella $(0-30 \mathrm{p}$. lievä haitta, 31-50p. kohtalainen ja yli 50 p. suuri haitta). Potilailla, joilla on diagnosoitu toiminnallinen äänihäiriö, VHI-pisteiden keskiarvon on todettu liikkuvan noin 33 pisteessä, ja terveäänisillä kontrolliryhmillä noin 10 pisteessä (ks. esim. Ohlsson \& Doteval, 2009). Alaluusuan ja Johanssonin tutkimuksessa (2003) toiminnallisiin ääniongelmiinsa terapiaa saaneiden asiakkaiden VHI-pisteiden keskiarvo oli ennen terapiaa 41 pistettä (keskihajonta 19,1, vaihteluväli 0-95).

Taustatekijöiden ja VHI-pisteiden yhteyttä tarkasteltaessa, havaittiin että kohtalaista (44-60p.) tai huomattavan suurta psykososiaalista haittaa (yli 61p.) äänestään kokevilla opiskelijoilla oli merkitsevästi useammin ylätie-infektioita ja he arvioivat äänensä tavallista korkeammaksi ja hiljaisemmaksi kuin muut opiskelijat. Myös opiskelijoiden kommenteis- sa nousi esiin, että opiskelijat kokivat korkean ja hiljaisen äänen ammatillista epävarmuutta lisääviksi äänenpiirteiksi opettajantyössä. Lisäksi suurempaa psykososiaalista haittaa kokevat opiskelijat arvioivat käyttävänsä ääntään vapaa-ajallaan keskimääräistä vähemmän. Jatkossa voitaisiin selvittää vaikuttaako vapaa-ajan äänenkäytön vähäisyys primaarisesti vai sekundaarisesti psykososiaalisen haitan määrään. Ryhmien väliset erot olivat tilastollisesti erittäin merkitseviä $(p<.01)$.

Äänioireiden, koetun psykososiaalisen haitan ja oman äänen häiriöisyyden arvion välillä todettiin positiivinen korrelaatio. Mitä enemmän opiskelijoilla $(n=190)$ esiintyi äänioireita, sitä suurempi oli myös äänioireiden vuoksi koettu psykososiaalinen haitta $\left(r_{s}=0,64, p<0,01\right)$ (ks. kuva 2). Kuten kuvan 2 hajontakaaviosta kuitenkin näkyy saman äänioirepistemäärän saaneilla opiskelijoilla voi kuitenkin olla hyvin erisuuruiset VHI-pisteet, toisin sanoen erilainen haittakokemus.

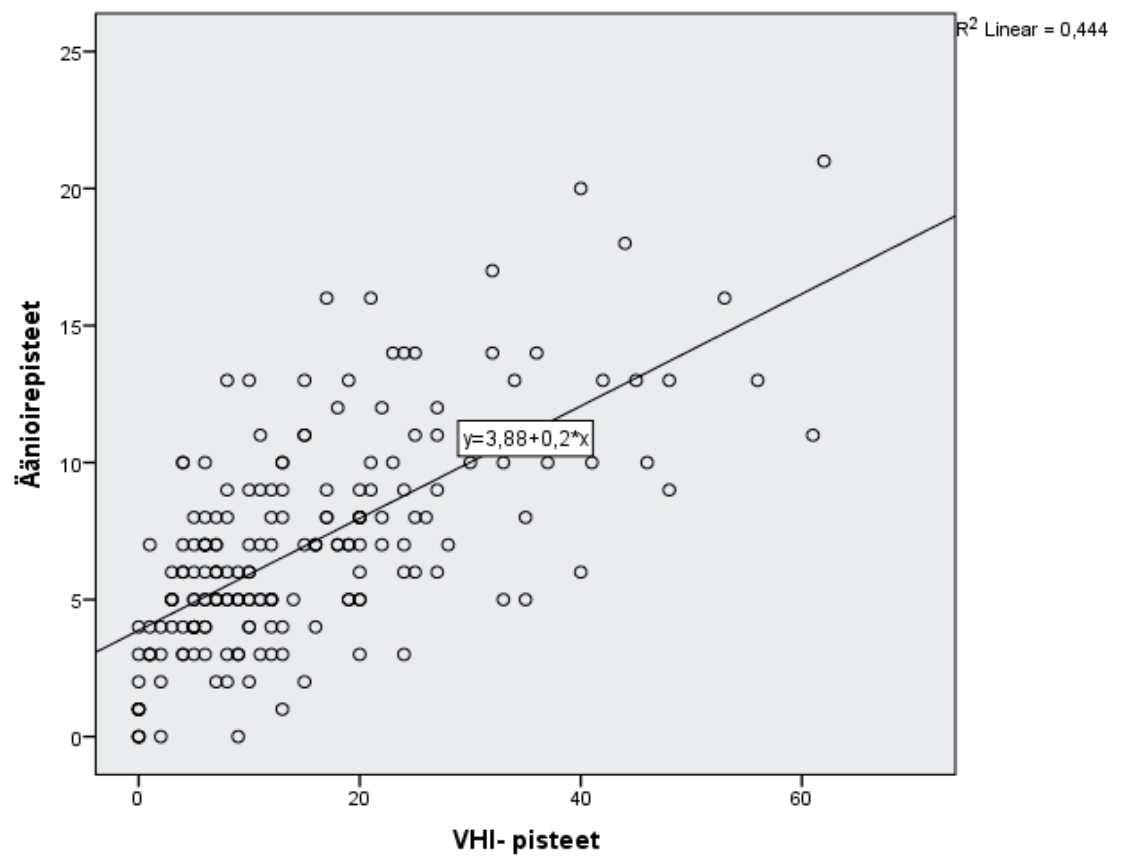

Kuva 2. VHI- ja äänioirepisteiden suhde. 
Äänioirekyselyn pisteet samoin kuin VHI:n pisteet olivat yhteydessä myös oman äänen häiriöisyyden arvioon. Mitä enemmän opiskelijat kokivat äänioireita, sitä suuremmaksi he yleensä arvioivat oman äänensä häiriöisyyden asteen $\left(r_{s}=0,58, p<0,01\right)$. Äänioireisten ryhmään $(n=70)$ kuuluvien opiskelijoiden VHI-pisteiden keskiarvo oli tilastollisesti merkitsevästi korkeampi kuin äänioireettomien $(n=120)$ ryhmään kuuluvien (ks. taulukko 3). He myös arvioivat oman äänensä häiriöisemmäksi kuin äänioireettomien ryhmään kuuluneet vastaajat.

Taulukko 3. Äänioireisten (vähintään kaksi oiretta viikoittain tai useammin) ja äänioireettomien ryhmien väliset erot äänioirekyselyssä, VHI-kyselyssä sekä oman äänen häiriöisyyden arviossa.

\begin{tabular}{|c|c|c|c|}
\hline & $\begin{array}{l}\text { Äänioireiset } \\
\quad(n=70)\end{array}$ & $\begin{array}{l}\text { Äänioireettomat } \\
(n=120)\end{array}$ & $\begin{array}{c}\text { Man Whitney } \\
\text { U-testi }\end{array}$ \\
\hline $\begin{array}{l}\text { Äänioirekyselyn } \text { pisteet }^{10} \\
\text { keskiarvo } \\
\text { keskihajonta }\end{array}$ & $\begin{array}{r}10,9 \\
3,1\end{array}$ & $\begin{array}{l}4,7 \\
1,9\end{array}$ & $\begin{array}{c}U=140,5 \\
Z=-11,15, p=.00\end{array}$ \\
\hline $\begin{array}{l}\text { VHI-kyselyn } \text { pisteet }^{2)} \\
\text { keskiarvo } \\
\text { keskihajonta }\end{array}$ & $\begin{array}{l}23,6 \\
14,4\end{array}$ & $\begin{array}{r}10,1 \\
8,3 \\
\end{array}$ & $\begin{array}{c}U=1594,5 \mathrm{Z}=\cdot 7,13 \\
p=.00\end{array}$ \\
\hline $\begin{array}{l}\text { Oman äänen } \\
\text { häiriöisyyden arvio3) } \\
\text { keskiarvo } \\
\text { keskihajonta }\end{array}$ & $\begin{array}{l}0,6 \\
0,6\end{array}$ & $\begin{array}{l}0,1 \\
0,2\end{array}$ & $\begin{array}{c}U=2178,0 Z=\cdot 7,60 \\
p=.00\end{array}$ \\
\hline
\end{tabular}

1) Äänioirekyselyn pisteet voivat vaihdella välillä 0-21pistettä.

2) VHI-kyselyn pisteet voivat vaihdella välillä 0-120 pistettä.

3) Vastaaja antaa arvon välillä 0-3, jossa 0 tarkoittaa normaalia ääntä, 1 lievästi häiriöistä, 2 melko häiriöistä ja 3 äärimmäisen häiriöistä ääntä.

\section{POHDINTA}

Säännölliset äänioireet, kuten esimerkiksi äänen käheys tai puhuessa tuntuva kipu kurkunpäässä, voivat olla merkkejä äänen liiallisesta kuormittumisesta (Sala \& Rantala, 2012, s. 24). Useissa aiemmissa kyselytutkimuksissa vastaajat onkin erilaisten äänioireiden määrän perusteella määritelty ääniongelmaisiksi (mm. Ohlsson ym., 2012) tai äänihäiriöisiksi (mm. Sala ym., 2002). Säännöllisesti koettuja äänioireita on pidetty hoitoon hakeutumisen aiheena (Simberg, 2004). Tämän tutkimuksen suuntaa antavat tulokset avaavat opiskeli- joiden kokemien äänioireiden ja äänihäiriön yhteyttä hieman toisesta näkökulmasta. Lähes $40 \%$ tähän tutkimukseen vastanneista kuului ryhmään, jolla oli kaksi tai enemmän päivittäistä tai viikoittaista äänioiretta, eli heidät olisi voitu aiempien tutkimusten tapaan määritellä ääniongelmaisiksi (mm. Ohlsson ym., 2012). Kuitenkin lähes 80 \% vastaajista koki äänensä normaaliksi. Subjektiivista psykososiaalista haittaa kuvaavan VHI-indeksin perusteella kohtalaista tai huomattavan suurta haittaa äänioireistaan koki ainoastaan 10 vastaajaa $(5 \%)$. 
Kuten Ohlssonin ym. (2012) tutkimuksessa myös tässä tutkimuksessa äänioireiden, koetun psykososiaalisen haitan ja oman äänen häiriöisyyden arvion väliltä löytyi tilastollinen yhteys. Tämä yhteys ei kuitenkaan ollut täysin yksiselitteinen. Joukossa oli useita opiskelijoita, joiden oman äänen häiriöisyyden arvio oli ristiriidassa VHI:Ilä mitatun psykososiaalisen haitan tai äänioireiden määrään kanssa. Tämän tutkimuksen tulosten perusteella näyttääkin siltä, että kaikki opiskelijat eivät koe äänioireitaan ongelmaksi. Useat opiskelijat pitivät äänioireitaan äänen normaalina käytöksenä, joka ei juurikaan häirinnyt heitä. He saattoivat kokea oman äänensä täysin normaaliksi, vaikka äänioirekyselyn tai VHI-kyselyn pisteiden perusteella heidät olisi voinut luokitella ääniongelmaisiksi. Tutkimustulosten perusteella voidaankin todeta, että säännöllisesti koettujen äänioireiden määrä ei aina tarkoita samaa kuin äänihäiriö tai ääniongelma. Äänihäiriötä tai ääniongelmaa ei siis tulisi määritellä ainoastaan äänioireiden perusteella. Kokemus oman äänen normaaliuudesta ja riittävyydestä äänioireista huolimatta korostui myös opiskelijoiden avoimissa kommenteissa. Rajanveto normaalin ja häiriöisen äänen välillä onkin haastavaa, koska normaaliksi koettujen äänien välillä on suuri variaatio (Mathieson, 2000, s. 3-7). Äänihäiriöisyyden kokemus on subjektiivinen, joten ihmiset kokevat oireistaan eriasteista haittaa (mm. Stemple ym., 2000, s. 2). Paljon ääneltään vaativa henkilö voi kokea oireensa invalidisoivina ja suurta haittaa elämälleen aiheuttavina, kun joku toinen ei häiriinny samanlaisista oireista lainkaan. Siihen, että oireet eivät aiheuta juurikaan haittaa, voi liittyä myös puhujan sopeutuminen ääniongelmiin. Kun oireet lisääntyvät vähitellen tai jatkuvat pitkään oirehtiva ääni voi alkaa tuntua normaalilta. Kiinnostavaa olisikin vielä tarkemmin selvittää sitä, minkälaisen äänen tai äänioireet puheammattilaiset itse kokevat häiriöiseksi ja minkälaisen normaaliksi.
Aiemmissa tutkimuksissa tietyillä opettajaryhmillä, esimerkiksi lastentarhanopettajilla (Sala ym., 2002), liikunnanopettajilla (Cantor Cutiva, ym., 2013) ja taide-aineiden opettajilla (Thibeault, 2004), on todettu esiintyvän enemmän äänioireita kuin muilla opettajilla. Tässä tutkimuksessa ei kuitenkaan todettu eri opettajankoulutusalojen opiskelijoiden välillä eroa äänioireiden esiintyvyydessä, psykososiaalisen haitan kokemuksessa tai oman äänen häiriöisyyden arvioissa. Tähän saattoi yhtäältä vaikuttaa se, että vastausprosentti $(8,6 \%)$ jäi oletettua pienemmäksi. Suuremmalla otoksella olisi mahdollisesti voitu löytää eroja opettajankoulutusten välillä, sillä pienehköt koulutusalakohtaiset otokset ovat voineet vaikuttaa siihen, että koulutusten välille ei syntynyt tilastollisesti merkitseviä eroja. Tässä tutkimuksessa ei myöskään ollut mukana liikunnanopettajaksi tai musiikinopettajaksi opiskelevia henkilöitä, mikä saattaa osaltaan selittää sitä, että eri opettajankoulutusalojen välille ei syntynyt eroja.

Kuten kyselytutkimuksissa yleensä, tässäkin tutkimuksessa vastaajat ovat saattaneet tulkita kyselyn väitteet eri tavoin. Tottumattoman voi myös olla hyvin vaikeaa arvioida omaa ääntään ja äänioireita. Avoimissa kommenteissa nousikin esiin se, että kaikki vastaajat eivät olleet täysin ymmärtäneet mitä käsitteellä "ääni” tarkoitettiin ja äänen oireiden erottelu on voinut olla monille haastavaa. Äänioirekyselyssä oireiden esiintymismääriä ei ole määritelty tarkasti, joten vastaajan ratkaistavaksi jää esimerkiksi, miten voimakkaat, pitkään kestävät tai mistä johtuvat oireet lasketaan mukaan. Taustatiedot äänen voimakkuudesta ja korkeudesta perustuivat opiskeljoiden itsearvioon, mikä ei luonnollisestikaan ole yhtä luotettava arviointitapa kuin esimerkiksi akustinen analyysi. Lisäksi monet VHI-kyselyn kysymykset, kuten "onko muilla vaikeuksia ymmärtää sinua”, ovat niin laajoja, että niihin voi vaikuttaa muutkin seikat kuin 
pelkästään ääni. Tutkimukseen osallistuminen oli vapaaehtoista, mikä saattaa jonkin verran vääristää tutkittavien joukkoa siten, että etenkin ne henkilöt, joilla on äänioireita ja ääniongelmia vastasivat kyselyyn. Tutkimustulosten pohjalta voidaan kuitenkin todeta, että vastaajien joukossa oli myös henkilöitä, joilla ei ollut lainkaan ääniongelmia ja jotka eivät kokeneet lainkaan haittaa äänestään.

Niin tässä kuin aiemmissakin tutkimuksissa (mm. Simberg, 2004) on todettu, että opettajien ja opettajaopiskelijoiden ääni kuormittuu ja heillä on paljon äänioireita. Toisaalta on myös havaittu, että äänioireistaan huolimatta opettajat ja opiskelijat hakeutuvat hoitoon vain harvoin (Thomas ym., 2006). Vaikka äänihäiriöiden ennaltaehkäisevän hoidon tai äänikoulutuksen vaikuttavuudesta ei vielä ole olemassa riittävästi tutkimusnäyttöä (Ruotsalainen ym., 2008), on kuitenkin havaittu, että äänitietoutta ja äänenkäyttökoulutusta saaneet opettajat tiedostavat ja tunnistavat ääniongelmansa paremmin ja hakeutuvat hoitoon herkemmin kuin opettajat, jotka eivät ole saaneet äänikoulutusta (Ilomäki, 2008, s. 61). Se, mikä saa opettajan tai opettajaopiskelijan etsimään apua ja muutosta tilanteeseensa, on vielä selvittämättä.

Ääni on tärkeä työväline tuleville opettajille, joten tieto äänen toiminnasta, ääniongelmista, niiden ehkäisystä ja hoidosta (ks. myös Williams \& Carding, 2005; Simberg, 2004; Roy ym., 2004) olisi olennaista jo opiskeluvaiheessa. Useat tutkimukset ovatkin korostaneet varhaista puuttumista ääniongelmiin ja tietoisuuden lisäämistä äänityöhön liittyvistä riskeistä jo opiskeluvaiheessa (mm. Simberg, 2004; Smith, 1997). Tällä hetkellä Helsingin yliopiston opettajaopiskelijoiden opetussuunnitelmaan ei kuulu äänenkäytön koulutusta. Tähän tutkimuksen osallistuneet opiskelijat vaikuttivat melko tietoisilta ääniongelmien riskeistä ja haitoista. Tästä huolimatta he kokivat, että eivät tiedä, miten ehkäistä ää- niongelmia. Äänikoulutuksen tarve ja huoli sen puutteesta nousivat toistuvasti esiin opiskelijoiden kommenteissa: "Ä̈nen tekniseen ja oikeaoppiseen käyttöön tulisi saada jo opekoulutuksessa eväitä - niin suuri os a se on tulevaa työtäpedagogiikan ohessa!”.

Käsitteet äänioire, ääniongelma ja äänibäiriö ovat monitulkintaisia ja sekoittuvat helposti. Nykyisin ajatellaan, että äänihäiriön määrittelyyn liittyy olennaisesti puhujan oma kokemus esimerkiksi siitä, että ääni ei täytä hänen ammatillisia ja/tai sosiaalisia tarpeitaan (mm. Connor \& Bless, 2014; Stemple ym., 2000). Mikäli säännölliset oireet eivät kuitenkaan aiheuta puhujalle psykososiaalista haittaa, ja hän on tyytyväinen ääneensä ja pitää ääntään normaalina, tuntuu tarpeettomalta leimata häntä äänihäiriöiseksi tai ääniongelmaiseksi.

Koetuista äänioireistaan huolimatta suurin osa tähän tutkimukseen osallistuneista opiskelijoista arvioi oman äänensä normaaliksi. Kun ääni koetaan normaalina, voi motivaatio ja sitoutuminen ennaltaehkäisevään äänikoulutukseen tai puheterapiaan olla vähäinen. Nähdäksemme olisikin tärkeää kohdentaa riittävästi apua erityisesti niille opiskelijoille, joille äänioireet aiheuttavat selvästi haittaa. Tämän tutkimuksen tulosten valossa näyttää siltä, että opettajaopiskelijoiden avun tarvetta ennakoivat ylähengitystieinfektioiden runsaus, närästys ja aiemmin diagnosoitu äänihäiriö. Näistä terveysongelmista kärsivillä opettajaopiskelijoilla on suurentunut äänikuormituksen riski. Tässä, kuten aiemmissakin tutkimuksissa (ks. esim. Franca, 2013; Simberg \& Sala, 2008, s. 259), äänioireiden lisääntymisen havaittiin liittyvän opintojen etenemiseen eli harjoittelujen ja töiden myötä lisääntyvään äänen kuormitukseen. Opettajaopiskelijoiden äänioireita voisikin olla järkevää kartoittaa etenkin pidempien harjoittelujaksojen yhteydessä. Harjoitteluissa tai työssä jo koetut ääniongelmat, huoli äänen 
kestämisestä tulevaisuuden työssä sekä opiskelijan oma arvio äänen häiriöisyydestä voivat olla signaaleja varhaisen avun tarpeesta.

Itsearviointiin perustuvat kyselyt antavat ääniongelmasta toisenlaista tietoa kuin kurkunpään kuvaus tai äänenlaadun akustinen mittaus tai kuulonvarainen arvio. Ihmisen oma subjektiivinen arvio ei aina olekaan täysin yhteneväinen foniatrin laryngoskopisen arvion ja asiantuntijoiden kuulonvaraisen arvion kanssa (Ilomäki, Mäki \& Laukkanen,2005). Avun tarpeen arvioinnissa ihmisen subjektiivinen kokemus oman äänen voinnista ja toimintakyvystä on kuitenkin ensisijaisen tärkeä. Itsearviontiin perustuvien kyselyiden avulla on suhteellisen vaivatonta selvittää opiskelijoiden kokemia äänioireita ja niistä aiheutuvaa haittaa sekä seuloa riskiryhmässä olevat opiskelijat, joiden ääniongelmiin tulisi puuttua jo opiskeluvaiheessa. Äänioirekyselyn ja psykososiaalista haittaa arvioivan VHI-kyselyn lisäksi on suositeltavaa kartoittaa terveydelliset riskitekijät, kuten ylähengitystieinfektioiden määrä, närästys ja mahdollisesti aiemmin diagnosoitu äänihäiriö. Myös palautumiskykyyn eli siihen, kuinka nopeasti ja hyvin ääni toipuu päivän rasituksesta, voisi olla hyvä kiinnittää huomiota arvioitaessa äänen häiriöisyyttä ja äänikuormituksesta aiheutuvaa haittaa (mm. Kankare, Geneid, Laukkanen \& Vilkman, 2012).

\section{LÄHTEET}

Alaluusua, S. \& Johansson M. (2003). Äänihäiriöiden aiheuttama psykososiaalinen haitta ja sen kuntoutuminen. Voice Handicap index 'n suomennoksen kokeilututkimus. Logopedian pro gradu -tutkielma. Helsingin yliopisto, fonetiikan laitos.

Connor, N. \& Bless, D. (2014). Functional and organic voice disorder. Teoksessa L. Cummings (toim.), The Cambridge handbook of communication disorder (s. 321-341). Cambridge: Cambridge University Press.
Cantor Cutiva, L. C., Vogel, I. \& Burdorf, A. (2013). Voice disorders in teachers and their associations with work-related factors: A systematic review. Journal of Communication Disorders, 46, 143-155.

Fairfield, C. \& Richards, B. (2007). Reported voice difficulties in student teachers: A questionnaire survey. British Journal of Educational Studies, 55, 409-425.

Hirsjärvi, S., Remes, P. \& Sajavaara, P. (2004). Tutki ja kirjoita. Helsinki: Tammi.

Ilomäki, I., Mäki, E. \& Laukkanen, A. M. (2005). Vocal symptoms among teachers with and without voice education. Logopedics Phoniatrics Vocology, 30, 171-174.

Ilomäki, I. (2008). Opettajien ääneen liittyvä työhyvinvointi ja äänikoulutuksen vaikutukset. Väitöskirja. Tampere University Press.

Jacobson, B. H., Johnson, A., Grywalski, C., Silbergleit, A., Jacobson, G. \& Benninger, M. (1997). The Voice Handicap Index (VHI): development and validation. American Journal of Speech-Language Pathology, 6, 66-70.

Jardim, R., Barreto, S. M. \& Assunção, A. A. (2007). Voice Disorder: Case definition and prevalence in teachers. Revista Brasileira de Epidemiologia (Brazilian Journal of Epidemiology), 10, 625-636.

Kankare, E., Geneid, A., Laukkanen, A. M. \& Vilkman, E. (2012). Subjective evaluation of voice and working conditions and phoniatric examination in kindergarten teachers. Folia Phoniatrica et Logopaedica, 64, 12-19.

Mathieson, L. (2000). Normal - disordered continuum. Teoksessa R. D. Kent \& M. J. Ball (toim.), Voice quality measurement (s. 3-12). San Diego: Singular Publishing Group.

Nummenmaa, L. (2008). Käyttäytymistieteiden tilastolliset menetelmät. Helsinki: Tammi.

Ohlsson A. C., Andersson E. M, Södersten M., Simberg, S. \& Barregård, L. (2012). Prevalence of voice symptoms and risk factors in teacher student. Journal of Voice, 26, 629-634.

Ohlsson, A.C. \& Doteval, H. (2009). Voice handicap index in Swedish. Logopedics Phoniatrics Vocology. 34, 60-66.

Roy, N., Merrill, R. M., Thibeault, S., Parsa, R. A., Gray, D., \& Smith, E.M. (2004). Prevalence of voice disorders in teachers and the general population. Journal of Speech, Language, and Hearing Research, 47, 281-293. 
Ruotsalainen, J.H., Sellman, J., Lehto, L. \& Verbeek, J. (2008). Systematic review of the treatment of functional dysphonia and prevention of voice disorder. Otolaryngology-Head and Neck Surgery, 138, 557-565.

Sala, E., Airo, E., Olkinuora, P., Simberg, S., Ström, U., Laine, A., Pentti, J. \& Suonpää; J. (2002). Vocal loading among day care center teachers. Logopedics Phoniatrics Vocology, 27, 21-28.

Sala, E. \& Rantala, R. (2012). Opetustilojen akustiikka ja ääniergonomia- tutkimuksesta toteutukseen. Työsuojelurahaston (TSR) hanke nro 109292.

Sala, E., Sihvo, M. \& Laine, A. (2003). Ä̈̈niergonomia. Toimiva ääni työvälineenä. Helsinki: Työterveyslaitos.

Simberg, S., Sala, E., Laine, A. \& Rönnemaa A. M. (2001). A fast and easy screening method for voice disorders among teacher students. Logopedics Phoniatrics Vocology, 26, 10-16.

Simberg, S., Sala, E. \& Rönnemaa, A.M. (2004). A comparison of the prevalence of vocal symptoms among teacher students and other university student. Journal of Voice, 18, 363-368.

Simberg, S. (2004). Prevalence of vocal symptoms and voice disorders among teacher students and teachers and a model of early intervention. Väitöskirja. Helsingin Yliopisto. Käyttäytymistieteellinen tiedekunta, puhetieteiden laitos.

Smith, E. (1997). Frequency and effects of teachers' voice problems. Journal of Voice, 11, 81-87. Stemple, J.C., Glaze, L.E. \& Gerdeman Klaben,
B. (2010). Clinical voice pathtology. Theory and management. (4. painos). San Diego: Singular Publishing Group.

Sukanen, O., Sihvo, M., Rorarius, E., Lehtihalmes, M., Autio, V. \& Kleemola, L. (2007). Voice Activity and Participation Profile (VAPP) in assessing the effects of voice disorders on patients' quality of life: Validity and reliability of the Finnish version of VAPP. Logopedics Phoniatrics Vocology, 32, 3-8.

Thibeault, S. L., Merril, R., Nelson, R., Gray, S. \& Smith, E. (2004). Occupational risk factors associated with voice disorders among teachers. Ann Epidemiol, 14, 786-792.

Thomas G, Kooijman, P. G., Cremers, C. W. \& De Jong, F. I. (2006). A comparative study of voice complaints and risk factors for voice complaints in female student teachers and practicing teachers early in their career. European Archives of Oto-Rhino-Laryngology, 263, 370-380.

Titze, I. R. (2001). Criteria for occupational risk in vocalization. Teoksessa P. H. Dejonckere (toim.), Occupational voice: Care and cure. Hague: Kugel Publications.

Williams, N. \& Carding, P. (2005). Occupational voice loss. Boca Raton: Taylor \& Francis group. Wilson, J. A., Web, A., Carding, P. N., Steen, I. N., MacKenzie, K. \& Deary, I. J. (2004). The Voice Symptom Scale (VoiSS) and the Vocal Handicap Index (VHI): A comparison of structure and content. Clinical Otolaryngology \& Allied Sciences, 29, 169-174.

\section{LIITE}

\section{Oman ä̈nen arviointilomake}

Kuinka usein sinulla on esiintynyt seuraavia oireita VIIMEISEN VUODEN aikana?

Päivittäin Viikoittain Harvemmin Ei ollenkaan

1. Onko äänesi aamuisin painunut tai käheä?

2. Rasittuuko tai väsyykö äänesi?

3. Madaltuuko tai käheytyykö äänesi puhuessa?

4. Pettääkö, sortuuko tai katkeileeko äänesi puhuessa?

5. Saatko äänesi huonosti kuulumaan?

6. Tuleeko puhuessa tarve selvittää kurkkua, yskiä tai rykiä?

7. Tuntuuko kurkunpään tienoilla kipua, jännitystä tai palan tunnetta? 


\section{TEACHER STUDENTS' VOICE SYMPTOMS AND THEIR CONNECTION TO THE EXPERIENCED PSYCHOSOCIAL IMPACT AND THE SELF-ASSESSMENT OF VOICE - A COMPARATIVE STUDY BETWEEN TRAINING FIELDS}

Roosa Britschgi, Coronaria kuntoutus Oy

Jaana Sellman, Motivoice Oy

The aim of this study is to investigate the prevalence of voice symptoms of teacher students of different subjects and examine the psychosocial harm caused to them by voice symptoms. In addition this study investigates how voice symptoms and psychosocial harm influences the assessment of one's voice. Teaching of some subjects is more linked to vocal risk factors and voice symptoms are more common among teachers of certain substances. Previous studies have found that teacher students have more voice symptoms than other university students, but there has not been any comparative research about the differences between teacher students studying different subjects. Previous studies have found correlation between the amount of voice symptoms and the psychosocial harm, but there has not been any Finnish studies regarding the relationship between the two.

A total of 190 students from all classes and training fields participated in the study. The data was gathered by electronic questionnaire, which consists of background information form and questionnaires about vocal symptoms (voice screening test) and the psychosocial impacts of voice disorders $(V H I)$.

The results show that voice symptoms are quite common among teacher students and about $40 \%$ of them reported frequently occurring voice symptoms. However, one of the main discoveries of this study is that almost $90 \%$ of the students did not have notable psychosocial impacts and almost $80 \%$ actually considered their voice normal. This research shows that students can regard their voice normal despite the fact that they have voice symptoms. The amount of voice symptoms and psychosocial harm was equally high among students of all different subjects.

Keywords: assessment of voice, psychosocial impact of voice disorders, survey, teacher students, voice symptoms 